\title{
The Potential of Gaseous Chlorine Dioxide for the Control of Citrus Postharvest Stem-End Rot Caused by Lasiodiplodia theobromae
}

\author{
Tian Zhong, ${ }^{1,2}$ Jiuxu Zhang, ${ }^{2}$ Xiuxiu Sun, ${ }^{3}$ Jingjing Kou, ${ }^{2}$ Zhike Zhang, ${ }^{2}$ Jinhe Bai, ${ }^{3}$ and Mark A. Ritenour ${ }^{2, \dagger}$ \\ ${ }^{1}$ Faculty of Medicine, Macau University of Science and Technology, Avenida Wai Long, Taipa, Macau 999078, China \\ ${ }^{2}$ Indian River Research and Education Center, University of Florida, Fort Pierce, FL 34945, U.S.A. \\ ${ }^{3}$ Horticultural Research Laboratory, Agricultural Research Service, U.S. Department of Agriculture, Fort Pierce, FL 34945, U.S.A.
}

\begin{abstract}
The focus of this study was to develop technologies using chlorine dioxide $\left(\mathrm{ClO}_{2}\right)$ gas to control postharvest stem-end rot of citrus caused by Lasiodiplodia theobromae. Mycelial growth of L. theobromae on potato dextrose agar (PDA) plugs was completely inhibited by a 24-h $\mathrm{ClO}_{2}$ exposure provided by $0.5 \mathrm{~g}$ of solid $\mathrm{ClO}_{2}$ generating granular mixture in a 7.7-liter sealed container. In vivo experiments were conducted on artificially inoculated Tango and naturally infected U.S. Early Pride mandarins. When $\mathrm{ClO}_{2}$ treatments were initiated 0 to $6 \mathrm{~h}$ after inoculation, decay development was significantly reduced as compared with the control, and higher $\mathrm{ClO}_{2}$ doses were more effective. A $\mathrm{ClO}_{2}$ treatment (using $3 \mathrm{~g}$ of generating mixture per 7.7-liter sealed container) administered $0 \mathrm{~h}$ after inoculation resulted in $17.6 \%$ Diplodia

control. Diplodia stem-end rot incidence of naturally infected fruit after using 6 or $9 \mathrm{~g}$ of generating mixture per 24-liter sealed box was 23.8 or $25.7 \%$, respectively, compared with $47.9 \%$ for control fruit. The $\mathrm{ClO}_{2}$ treatments had no negative effects on fruit quality characteristics including weight loss, firmness, puncture resistance, titratable acids (TAs), total soluble solids (TSSs), and rind color. Albedo $\mathrm{pH}$ at wounds was significantly reduced from 6.0 to 4.8 by the $\mathrm{ClO}_{2}$ treatments, whereas undamaged albedo remained at 5.8. In addition, no visible physiologic defects, such as peel browning and bleaching, were observed on $\mathrm{ClO}_{2}$-treated fruit. These results indicate that $\mathrm{ClO}_{2}$ gas has the potential to be developed as a component of an integrated citrus postharvest decay control system to minimize fruit losses.
\end{abstract} stem-end rot incidence compared with $95.6 \%$ in the control, whereas the same treatment administered $24 \mathrm{~h}$ after inoculation was much less effective, resulting in $63.0 \%$ incidence compared with $85.4 \%$ in the
Keywords: chlorine dioxide, citrus, Diplodia natalensis, Lasiodiplodia theobromae, postharvest, stem-end rot
Citrus is a popular and economically important horticultural crop that is widely cultivated in tropical and subtropical regions in the world. Citrus is regarded a universal fruit, with production in $>100$ countries spanning six continents (Saunt 1990). Citrus fruits are negatively affected by many factors from production to final consumption. Postharvest diseases can have a significant impact on fruit quality, marketing values, and economic returns.

Postharvest losses are more costly than production losses because of added harvesting and postharvest handling costs invested in the fruit. Furthermore, quality problems can reduce consumer confidence and thus reduce repeated buying. Several postharvest diseases such as green mold (caused by Penicillium digitatum), blue mold (caused by Penicillium italicum), stem-end rots (caused by Lasiodiplodia theobromae and Phomopsis citri), sour rot (caused by Galactomyces citri-aurantii), and anthracnose (caused by Colletotrichum gloeosporioides) occur in Florida, but stem-end rot caused by L. theobromae is the most common problem in early-season citrus (Ismail and Zhang 2004; Zhang 2007). Decay incidence often reaches 13 to $42 \%$ when fruits are not treated with a proper fungicide and/or placed in refrigeration (Smilanick et al. 2006). Stem-end rot caused by $L$. theobromae was historically called Diplodia stemend rot, and we shall continue to use that name in this report. $L$. theobromae is a facultative pathogen that completes its life cycle on dead twigs of citrus trees in the grove. Postharvest stem-end rot arises from the latent infection of citrus fruit button (i.e., calyx

${ }^{\dagger}$ Corresponding author: M. A. Ritenour; ritenour@ufl.edu

Funding: This work was supported by State Scholarship Fund of China Scholarship Council grant 201708440438 and Florida Citrus Packers through a U.S. Department of Agriculture Technical Assistance for Specialty Crops grant TASC-2019-02.

The author(s) declare no conflict of interest.

Accepted for publication 30 April 2021.

(C) 2021 The American Phytopathological Society and disk) tissues by L. theobromae in the field (Zhang 2007). It can be a severe problem, especially when fruits are ethylenedegreened, a practice that is often done on early-season fruit to enhance peel coloration for improved marketing (Barmore and Brown 1985; Brown 1975).

Furthermore, an increased Diplodia stem-end rot incidence has been observed on Huanglongbing (HLB)-affected fruit in Florida (Zhao et al. 2015). This may be partially because of the increased amount of weakened and dead wood in HLB-affected trees, which promotes growth and sporulation of $L$. theobromae (Ritenour et al. 2016). Therefore, there is a serious need for effective control measures for Diplodia stem-end rot of Florida citrus.

In an effort to manage postharvest decay and extend the shelf life of fresh citrus, a variety of approaches have been used, such as the application of the fungicides thiabendazole (TBZ), imazalil, and sodium-o-phenylphenate (SOPP) and the sanitizers ozone, hydrogen peroxide, peracetic acid, chlorine, and chlorine dioxide $\left(\mathrm{ClO}_{2}\right)$ (Allende et al. 2006; Beuchat 1996; Ritenour et al. 2016). $\mathrm{ClO}_{2}$ is approved by the U.S. Environmental Protection Agency (EPA) and the U.S. Food and Drug Administration (FDA) for application in water treatments (James 2006) and is a strong oxidizing agent with approximately 2.5 times higher activity than chlorine and with a broad biocidal effectiveness (Benarde et al. 1965). In most cases, $\mathrm{ClO}_{2}$ is used in gaseous or aqueous forms. Gaseous $\mathrm{ClO}_{2}$ has been proved to be more effective in deactivating microorganisms than aqueous $\mathrm{ClO}_{2}$ because of its superior ability to reach cavities and to penetrate produce with uneven surfaces ( $\mathrm{Du}$ et al. 2002). Moreover, the use of gaseous $\mathrm{ClO}_{2}$ has become more attractive because it minimizes changes in aroma and taste of the treated commodity (Couri et al. 1982).

Although the efficacy of gaseous $\mathrm{ClO}_{2}$ to control several microorganisms in different fruits and vegetables has been documented (Keskinen et al. 2009; Mahovic et al. 2007; Sun et al. 2014, 2017b), little research has focused on applications for control of postharvest decays of citrus, including Diplodia stem-end rot control. Our goal was to determine whether gaseous $\mathrm{ClO}_{2}$ treatments have the potential to manage postharvest Diplodia stem-end rot. The specific objectives of this study were to (i) determine the effect of $\mathrm{ClO}_{2}$ gas against 
L. theobromae in vitro, (ii) evaluate the effect of $\mathrm{ClO}_{2}$ gas on fruit decay development, and (iii) evaluate the effects of $\mathrm{ClO}_{2}$ gas treatment on the quality of treated mandarins.

\section{Materials and Methods}

Fruit and fungal pathogen. Tango fruits were obtained from a 3-year-old commercial grove in Saint Lucie County, Florida, and U.S. Early Pride fruits were harvested from 5-year-old trees at the U.S. Department of Agriculture-U.S. Horticulture Research farm in Fort Pierce, Florida. Both mandarins were still green, with a slightly lower total soluble solid (TSS; 8.7) than the minimum maturity standards (9.0) when harvested. Fruits were transported immediately after harvest to the University of Florida-Indian River Research and Education Center (UF/IRREC) in Fort Pierce and stored for 2 days at $10^{\circ} \mathrm{C}$ before the experiments. All fruits were free of defects and similar in size (average diameter approximately $80 \mathrm{~mm}$ ) and color. Extra fruits from each harvest that were not needed for the first experiment were stored at $10^{\circ} \mathrm{C}$ and used to repeat the same experiments (storage length approximately 5 days). Initial fruit quality perameters, including color, firmness, Brix, and acid content of U.S. Early Pride mandarin were measured before each experiment. An isolate of $L$. theobromae was obtained from citrus fruit (U.S. Early Pride) with stem-end rot at UF/IRREC and used in the study. The isolate was hyphal tipped for further purification. The identification of the isolate was further confirmed by PCR of the fungal DNA with the primers to amplify the sequences of the partial internal transcriber spacer (ITS) and translation elongation factor $1-\alpha$ $(\mathrm{EF} 1-\alpha)$ regions. The isolate was maintained on potato dextrose agar (PDA) in test tubes at $4^{\circ} \mathrm{C}$.

Chlorine dioxide gas generation and concentration measurement. $\mathrm{ClO}_{2}$ gas was generated by mixing two parts of dry granules (ICA TriNova, Newnan, GA) consisting of a zeolite carrier impregnated with sodium chlorite and an acid activator $\left(\mathrm{FeCl}_{3}\right)$ in a proprietary formulation. Upon mixing, $\mathrm{ClO}_{2}$ gas is released in a predictable and repeatable manner (Smith et al. 2015). Actual $\mathrm{ClO}_{2}$ concentrations were measured with a PortaSens II $\mathrm{ClO}_{2}$ gas detector (Analytical Technology, Collegeville, PA).

In vitro activity of $\mathrm{ClO}_{2}$ against mycelial growth of L. theobromae. The in vitro activity of $\mathrm{ClO}_{2}$ against $L$. theobromae was determined using a chamber method described by Sun et al. (2014) with minor changes. As shown in Figure 1A, airtight polypropylene containers with a 7.7-liter volume each were surface sterilized with $70 \%$ alcohol and used to provide a sealed environment for $\mathrm{ClO}_{2}$ exposure. L. theobromae was grown on PDA at $25^{\circ} \mathrm{C}$ for 3 days. For each treatment, a 6-cm-diameter petri dish containing 10 fungal PDA plugs (each $0.5 \mathrm{~cm}$ in diameter) from the edge of the fungal colony was placed on the bottom of the container. Before the container was sealed, a small sachet $(6 \times 6 \mathrm{~cm})$ made of semipermeable fiber film containing mixed $\mathrm{ClO}_{2}$-generating granules was attached to the inner side of the top lid with double-sided tape. Doses of $0,0.25,0.50,0.75,1.00,1.25$, or $1.50 \mathrm{~g}$ of mixed granules were applied to generate seven different concentrations of $\mathrm{ClO}_{2}$ in the containers. After a $24-\mathrm{h}$ exposure at $20^{\circ} \mathrm{C}$, the containers were opened, the petri dishes with fungal PDA plugs were removed and incubated at $20^{\circ} \mathrm{C}$ for an additional $24 \mathrm{~h}$, and mycelial growth was measured. The experiment was repeated three times.

Efficacy of $\mathrm{ClO}_{2}$ treatments for control of Diplodia stemend rot of inoculated mandarins. Based on the results of in vitro studies, four separate tests were conducted on Tango mandarins (Fig. 1B). In each test, a total of 225 fruits were randomly arranged into five groups: natural control (noninoculated fruit without $\mathrm{ClO}_{2}$ treatment), inoculated control (inoculated fruit without $\mathrm{ClO}_{2}$ treatment), single dose (inoculated fruit treated with $1 \mathrm{~g}$ of $\mathrm{ClO}_{2}$-generating granular mixture), double dose (inoculated fruit treated with $2 \mathrm{~g}$ of granular mixture), and triple dose (inoculated fruit treated with $3 \mathrm{~g}$ of granular mixture). For each group, the 45 fruits were arranged into three replicates of 15 fruits (approximately 2,225 $\pm 7.3 \mathrm{~g}$ ) each. Except for the natural control fruit group, all other fruits were inoculated by placing a PDA plug $(0.5 \mathrm{~cm}$ in diameter $)$ with $L$. theobromae mycelia at the stem-end cavity after the button tissues (disk and calyx) were removed with a sterile steel probe. The inoculated fruits and a petri dish containing 10 fungal PDA plugs were immediately $(0 \mathrm{~h}$, test 1$)$ placed into the 7.7-liter container and exposed to $\mathrm{ClO}_{2}$. The containers were sealed to prevent the gaseous $\mathrm{ClO}_{2}$ from diffusing out. The detailed steps of $\mathrm{ClO}_{2}$ treatment (sachet attaching, container sealing, and $\mathrm{ClO}_{2}$ concentration monitoring) were the same as for the in vitro experiment described above. After 24-h exposure of the fruit to $\mathrm{ClO}_{2}$ at $20^{\circ} \mathrm{C}$, the containers were opened, and the petri dishes with fungal PDA plugs were removed, incubated for an additional $24 \mathrm{~h}$ at $20^{\circ} \mathrm{C}$, and evaluated for fungal growth. Treated fruits were transferred to incubators at $30^{\circ} \mathrm{C}$ and $90 \% \mathrm{RH}$, and Diplodia stem-end rot incidences were recorded after 2 days. In tests 2,3 , and 4 , inoculated fruits were preincubated at $30^{\circ} \mathrm{C}$ and $90 \% \mathrm{RH}$ for 6,12 , or $24 \mathrm{~h}$, respectively, before $\mathrm{ClO}_{2}$ treatment to evaluate postinfection efficacies of $\mathrm{ClO}_{2}$ treatments. The experiment was repeated.

Efficacy of $\mathrm{ClO}_{2}$ treatments for control of Diplodia stemend rot of naturally infected mandarins. The experiment was conducted with U.S. Early Pride mandarins in unsealed polypropylene boxes (24 liters in volume) immediately after harvest. For each



Fig. 1. A, $\mathrm{ClO}_{2}$ exposure chamber for fungal potato dextrose agar plugs and fruit. $\mathrm{B}$, Schematic of experiments with Lasiodiplodia theobromae-inoculated fruit. 
treatment, 105 fruits were randomly divided into three replicates of 35 fruits each per box (average weight approximately 5,000 g). A $\mathrm{ClO}_{2}$ sachet $(6 \times 6 \mathrm{~cm})$ was attached to the inner surface of the top lid of each box with double-sided tape. The $\mathrm{ClO}_{2}$ doses were as follows: (1) control, no $\mathrm{ClO}_{2}$ treatment; (2) $3 \mathrm{~g}$ of $\mathrm{ClO}_{2}$ generating granular mixture; (3) $6 \mathrm{~g}$ of granular mixture; and (4) $9 \mathrm{~g}$ of granular mixture. After treatment at $20^{\circ} \mathrm{C}$ for $24 \mathrm{~h}$, the fruits were degreened with $5 \mu \mathrm{l} /$ liter of ethylene at $30^{\circ} \mathrm{C}$ and $90 \% \mathrm{RH}$ for $48 \mathrm{~h}$, incubated at $20^{\circ} \mathrm{C}$ and $75 \% \mathrm{RH}$ for up to 2 weeks, and then evaluated for Diplodia stem-end rot development. The decay incidence was calculated as $n_{\text {decay }} / n \times 100 \%$, where $n_{\text {decay }}$ is the number of decayed fruits and $n$ is the total number of fruit assessed in each replicate. This experiment was repeated three times.

Fruit quality evaluation. The effects of $\mathrm{ClO}_{2}$ treatments on fruit weight loss were evaluated using U.S. Early Pride mandarins from the naturally infected fruit experiments. All 35 fruits in each of three replicates of each treatment were numbered and individually weighed before $\mathrm{ClO}_{2}$ exposure. After $24 \mathrm{~h}$ of $\mathrm{ClO}_{2}$ treatment, $48 \mathrm{~h}$ of ethylene degreening ( $5 \mu \mathrm{l} /$ liter), and an additional 2 weeks of incubation at $20^{\circ} \mathrm{C}$, six fruits without decay were chosen from each replicate and weighed individually to obtain the final fruit weight loss values. The average weight loss of each treatment (three replicates) was expressed as the percentage loss of the initial total weight of the 18 selected fruits.

For determination of fruit firmness and peel puncture resistance, 18 extra U.S. Early Pride mandarins at the beginning of the naturally infected fruit experiments were used to determine the initial values. These were randomly divided into three replicates with six fruits each. At the end of the experiments, the six fruits used to measure weight loss as described above were also used to obtain final fruit firmness and peel puncture resistance values. Firmness was measured with a TA-XT2i texture analyzer (Stable Micro Systems, Godalming, United Kingdom) equipped with a 60-mm-diameter flat plate. The methods were adapted from those of Chen et al. (2016) with minor modifications. The fruits, were pressed by a flat plate at the equatorial area with a loading displacement of $12 \mathrm{~mm}$. The pretest, test, and posttest speeds all were set at $1 \mathrm{~mm} / \mathrm{s}$, and the trigger force was at $1 \mathrm{~N}$. Peel puncture resistance was measured using the same instrument as above with a 2 -mm-diameter cylindrical probe. The other parameters were set as follows: pretest and test speeds were both at $2 \mathrm{~mm} / \mathrm{s}$, posttest speed was at $6 \mathrm{~mm} / \mathrm{s}$, and the probe travel distance after touching the fruit surface was $15 \mathrm{~mm}$. The trigger force was $0.25 \mathrm{~N}$. Each fruit was punctured at three random locations along the fruit equatorial region.

After performance of the firmness and peel resistance tests, including the 18 extra fruits described earlier, the same fruits were used for TSS and titratable acidity (TA) tests. Each of six fruits from each replicate of the experiment treatment were peeled and homogenized together as a new replicate. The homogenates were centrifuged at $4,000 \times g$ for $10 \mathrm{~min}$, and the supernatant was collected and used for TSS and TA analysis. TSS content (in percentage) of the supernatant was determined with a PAL-1 pocket refractometer (Atago, Japan). Titratable acidity (expressed as percentage citric acid) was analyzed by titrating a $40-\mathrm{ml}$ supernatant aliquot to $\mathrm{pH} 8.3$ using a DL12 titrator (Mettler, Hightstown, NJ).

The effect of $\mathrm{ClO}_{2}$ on fruit rind color was evaluated using U.S. Early Pride mandarins in airtight polypropylene containers (7.7 liters). A total of 225 fruits were randomly divided into five groups with three replicates (boxes) of 15 fruits in each box (average weight approximately $2,000 \mathrm{~g})$. A small sachet $(6 \times 6$ $\mathrm{cm}$ ) containing mixed $\mathrm{ClO}_{2}$-generating granules was attached to the inner surface of the top lid of each box with double-sided tape. Five $\mathrm{ClO}_{2}$ doses, $0,1,3,6$, or $9 \mathrm{~g}$ of $\mathrm{ClO}_{2}$-generating granules per container, were used in this study. Before $\mathrm{ClO}_{2}$ treatment, three approximately 3-cm-diameter circles were drawn at equidistant locations around each fruit equator (12 fruits per treatment) with a permanent marker to ensure that consecutive color measurements were made at the same position each time. Initial rind color was measured before $(0 \mathrm{~h})$ and $24 \mathrm{~h}$ after $\mathrm{ClO}_{2}$ treatment with a colorimeter (CR400; Minolta). Measured parameters included lightness $\left(L^{*}\right)$, chroma $\left(C^{*}\right)$, and hue angle $\left(h^{\mathrm{o}}\right)$.
Fruit rind $\mathrm{pH}$ was measured on the same fruit used to evaluate peel color based on the method described by Montesinos-Herrero et al. (2011). Before $\mathrm{ClO}_{2}$ treatment, one random fruit from each treatment was wounded at three equidistant points around the equator by cutting the flavedo with a knife tip, leaving exposed albedo tissue $5 \mathrm{~mm}$ in diameter and $2 \mathrm{~mm}$ in depth. A volume of $30 \mu \mathrm{l}$ of distilled water was added to each wound, and $\mathrm{pH}$ was determined using a $\mathrm{pH}$ meter with a 2-mm-diameter combination electrode (Waterproof pHTestr 3+ Double Junction, Oakton Instruments, Vernon Hills, IL). The $\mathrm{pH}$ was measured immediately before the $\mathrm{ClO}_{2}$ treatments and afterward to obtain initial and final values, respectively. Three fresh wounds were also made on the same fruit immediately after $\mathrm{ClO}_{2}$ treatment, and the $\mathrm{pH}$ of fresh wounds was determined.

Data analysis. Data were analyzed with SPSS version 17.0 software (Experian QAS, Boston, MA) for one-way analysis of variance (ANOVA). When significant differences $(P<0.05)$ were found, the treatment means were compared using Duncan's multiple range test $(P<0.05)$. For repeated experiments, homogeneity of variance was tested by Bartlett's test, and the similar results were combined before data analysis.

\section{Results}

Chlorine dioxide generation and concentration changes during experiments. Generally, $\mathrm{ClO}_{2}$ concentrations gradually declined during the 24-h treatment (Fig. 2). The same dose of $\mathrm{ClO}_{2}$-generating granular mixture resulted in different $\mathrm{ClO}_{2}$ concentrations within the containers depending on the presence of fruit. Containers with 0.5 , 1.0 , or $1.5 \mathrm{~g}$ of granular mixture and sealed for $2 \mathrm{~h}$ accumulated average $\mathrm{ClO}_{2}$ concentrations of $43.7,65.8$, or 86.9 ppm, respectively, but only $12.5,26.5$, or $39.2 \mathrm{ppm}$, respectively, when $2,225 \mathrm{~g}$ of fruits were also sealed inside. At the end of the treatment $(24 \mathrm{~h}$ after initiation), the average concentrations for $0.5,1.0$, or $2.0 \mathrm{~g}$ of $\mathrm{ClO}_{2}$-generating granular mixture treatments without fruit were $19.5,25.9$, or $31.5 \mathrm{ppm}$, respectively, whereas those with fruit all decreased to near zero.

In vitro activity of $\mathrm{ClO}_{2}$ against mycelial growth of $L$. theobromae. The zone outlined in green in Figure 3 represents $\mathrm{ClO}_{2}$ treatments that completely inhibited the mycelial growth of $L$. theobromae on PDA plugs. No mycelial growth was observed from plugs treated with $0.5 \mathrm{~g}$ or more of $\mathrm{ClO}_{2}$-generating granular mixture without fruit, whereas at least $2.0 \mathrm{~g}$ of the granular mixture was needed to completely inhibit fungal mycelial growth on plugs in the experiments when fruit was included. As shown in Figures 2 and 3, a 24-h exposure with an initial $\mathrm{ClO}_{2}$ concentration above $43.7 \mathrm{ppm}$ and a final concentration above 19.5 ppm completely suppressed $L$. theobromae growth from PDA plugs. However, a dose of $1.5 \mathrm{~g}$ of $\mathrm{ClO}_{2}$-generating granular mixture did not completely prevent fungal growth in the experiment with fruit (Fig. 3).

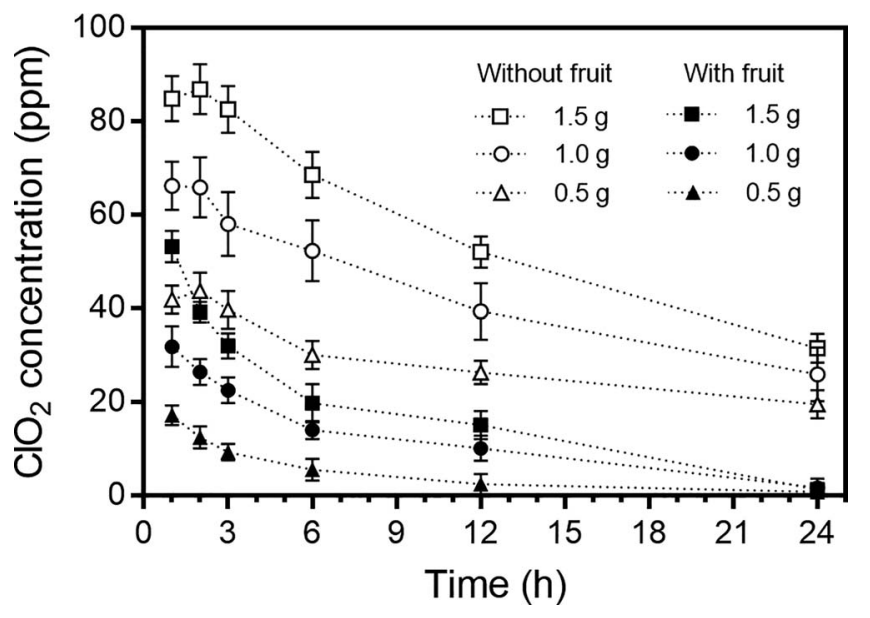

Fig. 2. Time-course profiles of $\mathrm{ClO}_{2}$ concentrations in experiments without and with inoculated Tango mandarins in 7.7-liter sealed containers at $20^{\circ} \mathrm{C}$. The average total weight of fruit per container was $2,225 \pm 7.3 \mathrm{~g}$. 
Efficacy of $\mathrm{ClO}_{2}$ for control of Diplodia stem-end rot of inoculated mandarins. No disease developed on natural control fruit that were not inoculated and not treated during incubation in all tests (Table 1). Inoculated control fruit that were not treated with $\mathrm{ClO}_{2}$ showed a range of Diplodia stem-end rot incidences from 82.7 to $95.6 \%$ in the four experiments. $\mathrm{ClO}_{2}$ treatments reduced Diplodia stem-end rot incidences compared with the inoculated controls in all tests $(P=0.05)$, demonstrating the effectiveness of $\mathrm{ClO}_{2}$ exposure in suppression of decay development under test conditions. The incidence of $17.7 \%$ was observed on the fruit treated with $3 \mathrm{~g}$ of $\mathrm{ClO}_{2-}$ generating mixture immediately $(0 \mathrm{~h})$ after inoculation, compared with $95.6 \%$ of decay incidence of inoculated control fruit in test 1. Test 2 showed that the increase of $\mathrm{ClO}_{2}$-generating mixture from 1 to $3 \mathrm{~g}$ per container resulted in the decrease of Diplodia stem-rot incidence on the inoculated fruit incubated for $6 \mathrm{~h}$ before $\mathrm{ClO}_{2}$ treatment. However, the increase of $\mathrm{ClO}_{2}$-generating granular mixture rates from 1 to $3 \mathrm{~g}$ per container did not similarly reduce decay incidences in tests 3 and 4, in which the fruits were inoculated for $12 \mathrm{~h}$ or $24 \mathrm{~h}$ before $\mathrm{ClO}_{2}$ treatment. In addition, Table 1 also shows that inoculated fruit incubated for 0 or $6 \mathrm{~h}$ (test 1 and 2) before treatment with $\mathrm{ClO}_{2}$-generating granular mixture at $3 \mathrm{~g}$ per container had significantly lower $(P=0.05)$ decay incidences than did those incubated for 12 or $24 \mathrm{~h}$ (tests 3 and 4 ).

Efficacy of $\mathrm{ClO}_{2}$ for control of Diplodia stem-end rot of naturally infected mandarins. Experiments with naturally infected fruit were repeated three times with similar results according to the Bartlett's test of homogeneity of variance and were combined (Fig. 4). The treatment with $3 \mathrm{~g}$ of $\mathrm{ClO}_{2}$-generating granular mixture did not significantly reduce Diplodia decay incidence, whereas the 6-g and 9-g doses significantly reduced decay incidence to 23.8 and $25.7 \%$, respectively, compared with the control incidence of $47.9 \%$. There was no significant difference in Diplodia stem-end rot incidence between the 6-g and 9-g treatments.

Effects of $\mathrm{ClO}_{2}$ exposure on mandarin quality. The firmness and TSS content of all fruit declined after 2 weeks of storage (Table 2). No significant treatment differences were found in fruit weight loss, firmness, and TSS. However, peel puncture resistance of control fruit and fruit treated with $3 \mathrm{~g}$ of $\mathrm{ClO}_{2}$-generating granular mixture declined significantly after storage, whereas the 6- and 9-g treatments did not. The TA content of control fruit decreased significantly after 2 weeks of incubation, whereas $\mathrm{ClO}_{2}$-treated fruit showed no significant changes. There were no significant differences in fruit peel color $\left(L^{*}, C^{*}\right.$, and $\left.h^{\circ}\right)$ as a result of the $\mathrm{ClO}_{2}$ treatments (data not shown). Albedo $\mathrm{pH}$ before the $\mathrm{ClO}_{2}$ treatments were 5.9 to 6.0 (Table 3). After $\mathrm{ClO}_{2}$ treatments, the albedo $\mathrm{pH}$ of original wounds decreased with increasing $\mathrm{ClO}_{2}$ treatment levels, down to a
$\mathrm{pH}$ of 4.8 at the highest level (9 $\mathrm{g}$ of $\mathrm{ClO}_{2}$-generating mixture). However, the $\mathrm{pH}$ of albedo from fresh wounds declined only slightly to 5.8, with no effects from the different $\mathrm{ClO}_{2}$ treatments. No visible physiologic defects, such as peel browning and bleaching, were observed on treated fruit.

\section{Discussion}

In the current study, the potential of gaseous $\mathrm{ClO}_{2}$ for the postharvest control of Diplodia stem-end rot on early-season harvested mandarin citrus was evaluated in vitro and on fruit. L. theobromae mycelial growth was completely inhibited with $0.5 \mathrm{~g}$ or more of $\mathrm{ClO}_{2}$-releasing product in a sealed 7.7-liter container. $\mathrm{ClO}_{2}$ treatments significantly reduced Diplodia stem-end rot incidences on inoculated and naturally infected mandarins compared with controls. Fruit inoculation tests also showed that the decay reduction efficacies were related to $\mathrm{ClO}_{2}$ concentrations and duration of pathogen postinfection before $\mathrm{ClO}_{2}$ treatment. In addition, no visible fruit injuries such as peel browning and bleaching were observed on $\mathrm{ClO}_{2}$-treated fruit.

In our current study, it was observed that $\mathrm{ClO}_{2}$ could be significantly absorbed by citrus fruit (Fig. 2). This should be an important factor to be considered when determining the $\mathrm{ClO}_{2}$ treatment rates for controlling citrus fruit decay. According to previously reported

Table 1. Effects of different doses of a $\mathrm{ClO}_{2}$-generating granular mixture on Diplodia stem-end rot (Lasiodiplodia theobromae) in inoculated Tango mandarin at different infection stages after $24 \mathrm{~h}$ of $\mathrm{ClO}_{2}$ exposure at $20^{\circ} \mathrm{C}$ and 2 days of incubation at $30^{\circ} \mathrm{C}$ and $90 \% \mathrm{RH}$

\begin{tabular}{|c|c|c|c|c|}
\hline \multirow[b]{2}{*}{ Treatment $^{\mathrm{x}}$} & \multicolumn{4}{|c|}{ Incidence of Diplodia stem-end rot (\%) } \\
\hline & $\begin{array}{c}\mathbf{0} \mathbf{h}^{\mathbf{y}} \\
(\text { test 1) }\end{array}$ & $\begin{array}{c}6 \mathrm{~h} \\
\text { (test 2) }\end{array}$ & $\underset{(\text { test 3) }}{12 \mathrm{~h}}$ & $\begin{array}{c}24 \mathrm{~h} \\
(\text { test 4) }\end{array}$ \\
\hline Natural control & $0 \mathrm{c}$ & $0 \mathrm{e}$ & $0 \mathrm{c}$ & $0 \mathrm{c}$ \\
\hline Inoculated control & 95.6 a $\mathrm{A}^{\mathrm{z}}$ & 86.7 a $\mathrm{AB}$ & 82.7 a B & 85.4 a B \\
\hline \multicolumn{5}{|c|}{$\mathrm{ClO}_{2}$ granular dose $(\mathrm{g})$} \\
\hline 1 & $68.6 \mathrm{~b} \mathrm{~A}$ & $62.2 \mathrm{~b} \mathrm{~A}$ & $66.7 \mathrm{~b} \mathrm{~A}$ & $66.7 \mathrm{~b} \mathrm{~A}$ \\
\hline 2 & $51.0 \mathrm{~b} \mathrm{BC}$ & $42.2 \mathrm{c}$ & $72.0 \mathrm{ab} \mathrm{A}$ & $68.5 \mathrm{~b} \mathrm{AB}$ \\
\hline 3 & 17.7 c B & $28.9 \mathrm{~d} B$ & $69.3 \mathrm{~b} \mathrm{~A}$ & $63.0 \mathrm{~b} \mathrm{~A}$ \\
\hline
\end{tabular}

${ }^{\mathrm{x}}$ Natural control $=$ noninoculated fruit without $\mathrm{ClO}_{2}$ treatment; inoculated control = inoculated fruit without $\mathrm{ClO}_{2}$ treatment.

${ }^{\mathrm{y}}$ Fruits were preincubated for $0,6,12$, and $24 \mathrm{~h}$, respectively, after inoculation and before $\mathrm{ClO}_{2}$ exposure.

${ }^{\mathrm{z}}$ The lowercase letters a to $\mathrm{d}$ in the same column indicate significant differences among the treatments based on Duncan's multiple range test $(P=0.05)$. The capital letters $\mathrm{A}$ to $\mathrm{C}$ in the same row indicate significant differences among different preincubation times based on Duncan's multiple range test $(P=0.05)$.



Fig. 3. Mycelial growth of Lasiodiplodia theobromae from potato dextrose agar plugs (10 plugs per petri dish) in the absence or presence of Tango mandarins (average total weight $=2,225 \pm 7.3 \mathrm{~g} / 7.7$-liter container). Petri dishes were treated with different $\mathrm{ClO}_{2}$ doses for $24 \mathrm{~h}$ at $20^{\circ} \mathrm{C}$ in sealed plastic containers and were then incubated without $\mathrm{ClO}_{2}$. Dishes outlined in green represent treatments that completely inhibited mycelial growth. 
research, various factors including temperature, $\mathrm{RH}$, light, and the presence of fruit can result in the loss of $\mathrm{ClO}_{2}$ concentration in a sealed tank (Arango et al. 2016; Sun et al. 2017b). This suggests that the $\mathrm{ClO}_{2}$ concentration loss observed in this study was mainly because of the absorption by fresh fruit, PDA medium, and even the container material. The difference in $\mathrm{ClO}_{2}$ concentrations between the two experiments (with or without fruit) indicates that fresh citrus fruits are primarily responsible for $\mathrm{ClO}_{2}$ absorption under the test conditions. Previous research on berries reported similar results, with $\mathrm{ClO}_{2}$ absorption by the fruit being a rapid process in which the strawberries consumed $15 \%$ of a 5 ppm of $\mathrm{ClO}_{2}$ treatment within 7 min (Arango et al. 2014). In another study, the $\mathrm{ClO}_{2}$ concentration in an empty tank approached $9 \mathrm{ppm}$ in $2 \mathrm{~h}$, whereas the concentration in the tank containing cantaloupes was near zero (Smith et al. 2015). In our current study, the in vitro results were supported by the $\mathrm{ClO}_{2}$ concentration change curves where the $\mathrm{ClO}_{2}$ level of $1.5 \mathrm{~g}$ of granular mixture with fruit declined to less than the level of $0.5 \mathrm{~g}$ of granular mixture without fruit, which fell below the minimum inhibitory $\mathrm{ClO}_{2}$ concentration for Diplodia stem-end rot control. Since citrus fruit absorbs $\mathrm{ClO}_{2}$, the actual available $\mathrm{ClO}_{2}$ that kills or

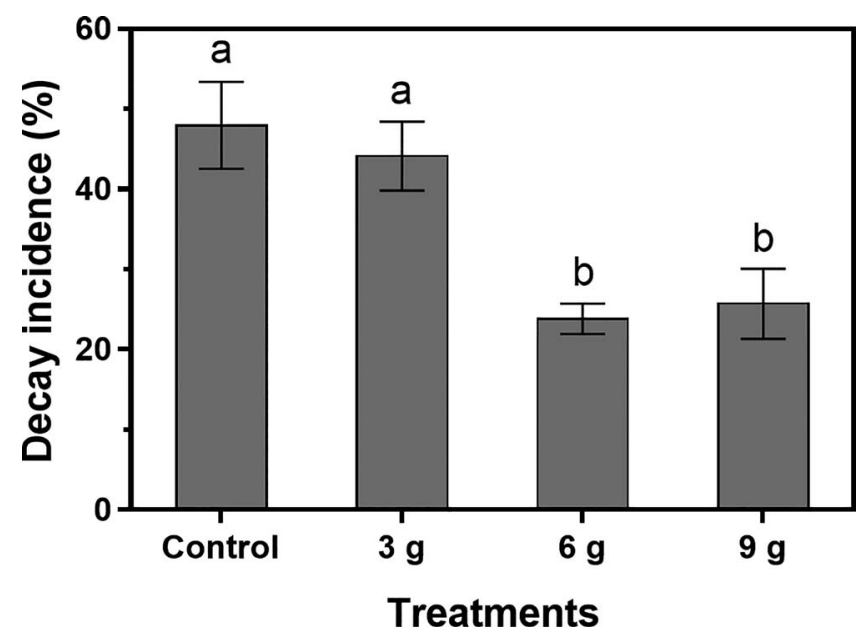

Fig. 4. Effects of different doses of a $\mathrm{ClO}_{2}$-generating granular mixture on Diplodia stem-end rot (Lasiodiplodia theobromae) in naturally infected U.S. Early Pride mandarin. Fruits were treated with 0 (control), 3,6 , and $9 \mathrm{~g}$ of $\mathrm{ClO}_{2}$-generating granular mixture, at $20^{\circ} \mathrm{C}$ for $24 \mathrm{~h}$, degreened with $5 \mathrm{ppm}$ of ethylene at $30^{\circ} \mathrm{C}$ and $90 \% \mathrm{RH}$ for $48 \mathrm{~h}$, and then incubated at $20^{\circ} \mathrm{C}$ and $75 \% \mathrm{RH}$ for up to 2 weeks. Three similar results of the repeated experiments were combined after Bartlett's test of homogeneity of variance for all the treatments. Letters above the bars indicate significant differences among treatments based on Duncan's multiple range test $(P<0.05)$.

Table 2. Effects of different doses of a $\mathrm{ClO}_{2}$-generating granular mixture on fruit quality of U.S. Early Pride mandarin after $24 \mathrm{~h}$ of $\mathrm{ClO}_{2}$ exposure at $20^{\circ} \mathrm{C}, 48 \mathrm{~h}$ of ethylene degreening $\left(5 \mu \mathrm{l} /\right.$ liter of ethylene, $30^{\circ} \mathrm{C}$, and $90 \% \mathrm{RH})$, and 2 weeks of incubation at $20^{\circ} \mathrm{C}$

\begin{tabular}{lccccc}
\hline Treatment & $\begin{array}{c}\text { Weight } \\
\text { loss }(\%)\end{array}$ & $\begin{array}{c}\text { Firmness } \\
(\mathbf{N})\end{array}$ & $\begin{array}{c}\text { Puncture } \\
\text { resistance (N) }\end{array}$ & $\begin{array}{c}\text { TSS }^{\mathbf{v}} \\
(\%)\end{array}$ & $\begin{array}{c}\mathbf{T A}^{\mathbf{w}} \\
(\%)\end{array}$ \\
\hline Initial $^{\mathrm{x}}$ & & $165.5 \mathrm{a}$ & $15.1 \mathrm{a}$ & $8.7 \mathrm{a}$ & $0.5 \mathrm{a}$ \\
$\mathrm{Control}^{\mathrm{y}}$ & $5.2 \mathrm{a}^{\mathrm{z}}$ & $110.1 \mathrm{~b}$ & $11.6 \mathrm{~b}$ & $8.3 \mathrm{~b}$ & $0.4 \mathrm{~b}$ \\
$\mathrm{ClO}_{2}$-generating & & & & & \\
$\quad \begin{array}{l}\text { mixture (g) } \\
3\end{array}$ & $5.1 \mathrm{a}$ & $120.7 \mathrm{~b}$ & $12.5 \mathrm{~b}$ & $8.3 \mathrm{~b}$ & $0.5 \mathrm{a}$ \\
6 & $4.6 \mathrm{a}$ & $120.8 \mathrm{~b}$ & $14.5 \mathrm{a}$ & $8.3 \mathrm{~b}$ & $0.5 \mathrm{a}$ \\
9 & $5.4 \mathrm{a}$ & $120.3 \mathrm{~b}$ & $15.3 \mathrm{a}$ & $8.4 \mathrm{~b}$ & $0.5 \mathrm{a}$ \\
\hline
\end{tabular}

${ }^{\mathrm{v}} \mathrm{TSS}=$ total soluble solid content.

${ }^{\mathrm{w}} \mathrm{TA}=$ titratable acid content.

${ }^{x}$ Initial means fruit qualities immediately before the $\mathrm{ClO}_{2}$ treatments.

${ }^{\mathrm{y}}$ Control $=$ fruit not treated with $\mathrm{ClO}_{2}$.

${ }^{\mathrm{z}}$ Letters within a column indicate significant difference based on Duncan's multiple range test $(P=0.05)$. suppresses the fungal pathogens should be considered. The time duration of $\mathrm{ClO}_{2}$ releasing from its generating granular mixtures should also be considered. A fast-release type of $\mathrm{ClO}_{2}$-generating granular mixtures was used in this study, and it released $>90 \%$ of its $\mathrm{ClO}_{2}$ in about $30 \mathrm{~min}$ after the initial application (date not shown). Therefore, the determination of optimum application rates of $\mathrm{ClO}_{2}$ should consider the decay control efficacy, controlled $\mathrm{ClO}_{2}$ release types, fruit absorption, and the potential impact of fruit peel physiology and quality by $\mathrm{ClO}_{2}$.

Postharvest Diplodia stem-end rot results from latent L. theobromae infections in the field before harvest (Ismail and Zhang 2004; Zhang 2014). After harvest, the pathogen starts to further infect fruit tissues after an abscission zone forms between fruit and fruit button. Therefore, when inoculated fruit were used for evaluating the efficacy of $\mathrm{ClO}_{2}$ for Diplodia stem-end rot control in this study, the fruit button tissues (calyx and disk) were removed before inoculating the fruit stem-end cavity with $L$. theobromae mycelia. Inoculated fruit were also incubated at $30^{\circ} \mathrm{C}$, which is the optimal temperature for this fungal growth (Zhang 2007). Under these conditions, the pathogen readily infected and quickly spread into fruit tissues. The time between fruit inoculation and $\mathrm{ClO}_{2}$ treatment resulted in significant differences in disease incidence and decay control efficacy (Table 1). Different incubation periods for inoculated fruit before $\mathrm{ClO}_{2}$ treatment in this study was to simulate the relationship between $L$. theobromae natural infection process and the application time of the decay control measures. Thus, when fruit were exposed to $\mathrm{ClO}_{2}$ immediately $(0 \mathrm{~h})$ after inoculation, $\mathrm{ClO}_{2}$ was most effective because the contact occurred before the fungus could infect fruit tissues. However, after 12 and $24 \mathrm{~h}$ postinoculation, L. theobromae had become more established resulting in almost as much infection as in the untreated, inoculated control.

Although a number of studies reported good penetration ability of $\mathrm{ClO}_{2}$ gas into the fruit stem scar (Han et al. 2001; Lee et al. 2015; Park and Kang 2015; Wang et al. 2019), our results indicated less penetration activity as it was effective only before the fungus penetrated inside fruit tissues (Table 1). However, the interactions between $\mathrm{ClO}_{2}$ gas, fruit tissues, fruit physiologic responses, and pathogens within the tissue, especially under different environmental conditions are still not clear and additional studies are needed.

In Florida, citrus fruit harvested early in the season are often subjected to degreening treatment (using ethylene) to stimulate the breakdown of chlorophyll in the flavedo and reveal the yellow to orange carotenoid pigments before marketing the fruit. It has been reported that ethylene degreening practice significantly increases the development of Diplodia stem-end rot and anthracnose (caused by C. gloeosporioides) on citrus fruit (Ismail and Zhang 2004; Plaza et al. 2004; Zhang 2014). This is largely because of ethylene

Table 3. Effects of different doses of a $\mathrm{ClO}_{2}$-generating granular mixture on the $\mathrm{pH}$ of fruit albedo of U.S. Early Pride mandarin immediately before and after $24 \mathrm{~h}$ of $\mathrm{ClO}_{2}$ exposure in 7.7-liter sealed containers

\begin{tabular}{llcl}
\hline & \multicolumn{3}{c}{ pH of fruit albedo } \\
\cline { 2 - 4 } ClO $_{2}$ granular & \multicolumn{3}{c}{ Final $^{\mathbf{w}}$} \\
\cline { 2 - 4 } dose $(\mathbf{g})$ & Initial $^{\mathbf{v}}$ & Original $^{\mathbf{x}}$ & Fresh $^{\mathbf{y}}$ \\
\hline 0 & $5.9 \mathrm{aA}^{\mathrm{z}}$ & $5.9 \mathrm{aA}$ & $5.8 \mathrm{aA}$ \\
1 & $6.0 \mathrm{aA}$ & $5.6 \mathrm{bC}$ & $5.8 \mathrm{aB}$ \\
3 & $6.0 \mathrm{aA}$ & $5.4 \mathrm{cC}$ & $5.8 \mathrm{aB}$ \\
6 & $5.9 \mathrm{aA}$ & $5.1 \mathrm{dC}$ & $5.8 \mathrm{aB}$ \\
9 & $6.0 \mathrm{aA}$ & $4.8 \mathrm{eC}$ & $5.8 \mathrm{aB}$ \\
\hline
\end{tabular}

${ }^{v}$ Initial data were measured immediately before $\mathrm{ClO}_{2}$ treatments.

${ }^{\text {w }}$ Final data were measured immediately after $\mathrm{ClO}_{2}$ treatments.

${ }^{\mathrm{x}}$ Original data were measured at wounds made before the $\mathrm{ClO}_{2}$ treatments and were exposed to $\mathrm{ClO}_{2}$ for $24 \mathrm{~h}$ before the final $\mathrm{pH}$ measurement.

${ }^{y}$ Fresh data were measured at new wounds made after the $\mathrm{ClO}_{2}$ treatments.

${ }^{\mathrm{z}}$ The lowercase letters (a to e) in the same column indicate significant differences among the treatments based on Duncan's multiple range test $(P=0.05)$. The capital letters (A to $C)$ in the same row indicate significant differences among the initial and final values based on Duncan's multiple range test $(P=0.05)$. 
promoting fruit senescence and abscission zone formation leading to greater decay (Zhang 2014). Our current results indicate that $\mathrm{ClO}_{2}$ treatment could be more effective for Diplodia stem-end rot control when it is applied before or during fruit degreening.

Other decays such as green mold $(P$. digitatum) can also be a problem on fresh Florida citrus. Testing conditions in our studies (i.e., high fruit incubation temperatures, ethylene degreening and fruit inoculation) favored $L$. theobromae growth and infection. Thus, Diplodia stem-end rot developed rapidly, whereas other diseases were rare. Thus, $\mathrm{ClO}_{2}$ effects on these other decays is not clear and further study is needed.

Effective control of citrus postharvest diseases requires an integrated management system including practices before and after harvest. During postharvest handling, fruit are commonly treated with fungicides such as thiabendazole (TBZ), imazalil and sodium-o-phenylphenate (SOPP) for decay control. TBZ is generally considered more effective for Diplodia decay control than imazalil and SOPP (Ismail and Zhang 2004). Fungicides are commonly applied to citrus fruit as an aqueous drench before degreening, aqueous treatments on the packing line, and/or added to the fruit coating to provide continued disease suppression during fruit shipping, storage, and marketing. The use of $\mathrm{ClO}_{2}$ could provide an additional measure to be included in the current citrus decay control system to minimize fruit decay losses, maintain citrus fruit quality, and prolong fruit shelf life.

Fungicide application is the core component of the integrated postharvest decay control system of fresh citrus (Zhang 2007). However, because of increasingly restrictive regulations, environmental and health concerns, and pathogen resistance development, alternatives and safe methods to chemicals for citrus postharvest decay control are constantly needed. $\mathrm{ClO}_{2}$ gas is a strong oxidizing agent with approximately 2.5 times higher activity than chlorine and with a broad biocidal effectiveness (Benarde et al. 1965). It has also been reported that the residues of $\mathrm{ClO}_{2}$-treated oranges were found to be at very low levels (Trinetta et al. 2011). Therefore, the use of $\mathrm{ClO}_{2}$ treatment as a component in a postharvest decay control system may reduce fungicide usage levels and costs, potential fungicide resistance development, and the fungicide residue problems for citrus postharvest decay control.

Fruit quality changes continuously during postharvest storage (Ladanyia 2010). Both fruit weight and firmness decline after harvest, largely as a result of fruit moisture loss (Paniagua et al. 2013). However, $\mathrm{ClO}_{2}$ treatment significantly maintained fruit puncture resistance during storage, which is similar to what was found with $\mathrm{ClO}_{2}$-treated blueberries (Sun et al. 2014). This may be explained by the inhibitory effect of $\mathrm{ClO}_{2}$ on enzymes such as peroxidase and polyphenol oxidase (Wang et al. 2011), respiration (Guo et al. 2014), metabolism (Gómez-López et al. 2008), and ethylene production (Aday and Caner 2011), which all play an important role in fruit softening. Reduced fruit respiration may be reflected in fewer changes in TSS and TA (Aday et al. 2013). However, no significant differences in TSS were found among the treatments and control. TA, mainly malic and citric acid, is directly related to the concentration of organic acids present in fruit and plays an important role in pH regulation of the cell (Kader 1991). In this sense, the higher TA values of $\mathrm{ClO}_{2}$-treated fruit compared with the control suggests that $\mathrm{ClO}_{2}$ slowed respiration and significantly maintained the organic acid content.

High concentrations of $\mathrm{ClO}_{2}$ increased bleaching on fruit flavedo, which resulted in low brightness levels (Sun et al. 2019). Fruit color changed from vivid to gray, which indicated fruit discoloration under high concentration of $\mathrm{ClO}_{2}$ (Sy et al. 2005). However, no significant changes in color after $\mathrm{ClO}_{2}$ exposure were detected in the current studies. Our study also showed that fruit albedo $\mathrm{pH}$ significantly decreased in both original and fresh wounds after $\mathrm{ClO}_{2}$ exposure. This is probably because of the oxidation of carbohydrates to carboxylic acid by dissolved $\mathrm{ClO}_{2}$ in fruit tissue (Aday and Caner 2011). Additionally, the original wounds were open during the whole course of exposure and were in direct contact with $\mathrm{ClO}_{2}$. Thus, it is believed the higher concentration led to more absorption of $\mathrm{ClO}_{2}$, which caused the decrease in albedo $\mathrm{pH}$. Conversely, albedo of fresh wounds was not directly exposed to $\mathrm{ClO}_{2}$ and maintained significantly higher $\mathrm{pH}$ than that of original wounds. Thus, fruit flavedo tissues may provide some barrier property against $\mathrm{ClO}_{2}$ penetration.

High $\mathrm{ClO}_{2}$ concentrations can cause phytotoxicity, physiologic defects, or injury to fruits and vegetables. Exposure to higher $\mathrm{ClO}_{2}$ concentrations in grapefruit packaging during storage caused fruit peel browning, whereas lower rates did not (Sun et al. 2017a). Mahovic et al. (2007) reported that the higher doses of $\mathrm{ClO}_{2}$ caused stem scars on tomato fruit to become cracked, sunken, and bleached. However, under our test conditions, we did not observe phytotoxicity injury or obvious fruit peel disorders from any of the $\mathrm{ClO}_{2}$ treatments.

$\mathrm{ClO}_{2}$ exists as a greenish yellow to orange gas at room temperature, and it is explosive in air when concentrations exceed $10 \% \mathrm{vol} /$ vol (WHO 2002). Additionally, $\mathrm{ClO}_{2}$ is harmful and a severe irritant to skin, eyes, and the respiratory tract (WHO 2002). The U.S. Occupational Safety and Health Administration (OSHA) permissible exposure limits for $\mathrm{ClO}_{2}$ gas are as follows: $0.1 \mathrm{mg} / \mathrm{liter}$ of 8-h timeweighted average (TWA), and $0.3 \mathrm{mg} /$ liter of short-term exposure limit (STEL). $\mathrm{ClO}_{2}$ gas was generated in the current study by combining two solid granular products. Therefore, operator exposure to $\mathrm{ClO}_{2}$ gas is limited. In addition, the fast-release type of $\mathrm{ClO}_{2}$-generating products used released most of their $\mathrm{ClO}_{2}$ in about $30 \mathrm{~min}$, so that most $\mathrm{ClO}_{2}$ will be absorbed by the citrus fruit in the closed atmosphere well before the rooms or containers are opened again, limiting exposure to operators. Therefore, with personal protective equipment, the safety of applying these types of $\mathrm{ClO}_{2}$ treatments on citrus fruit should be secured.

Many reports have shown that $\mathrm{ClO}_{2}$ gas treatments of various fruits and vegetables can reduce populations of food-borne pathogens such as Escherichia coli and Salmonella species (Lee et al. 2004; Sun et al. 2017b). $\mathrm{ClO}_{2}$ gas at $5 \mathrm{mg} /$ liter completely inhibited the growth of $E$. coli on inoculated grapefruit after $24 \mathrm{~h}$ of incubation at $20^{\circ} \mathrm{C}$ (Sun et al. 2017b). It had been reported that the residue levels of $\mathrm{ClO}_{2}$ on $\mathrm{ClO}_{2}$ gas-treated oranges were much lower (Trinetta et al. 2011). Fresh citrus such as mandarins are generally consumed by removing the fruit peels, which would further reduce $\mathrm{ClO}_{2}$ residues of treated fruit if any were initially present. Our current study also showed that $\mathrm{ClO}_{2}$ gas had no negative effects on fruit quality characteristics including weight loss, firmness, puncture resistance, titratable acids, total soluble solids and rind color. This suggests that the $\mathrm{ClO}_{2}$ gas treatment has good potential to maintain fresh citrus fruit quality and safety for the final consumers.

In summary, the $\mathrm{ClO}_{2}$ gas treatments reported here show promise for reducing Diplodia stem-end rot of citrus fruit. The antifungal activity of gaseous $\mathrm{ClO}_{2}$ against $L$. theobromae was demonstrated in vitro and in vivo. In addition, $\mathrm{ClO}_{2}$ treatments generally resulted in no negative effects on fruit quality and, in some cases, maintained peel puncture resistance and juice TA during storage. This suggests that $\mathrm{ClO}_{2}$ gas delivered by this new application technology have potential for integration into an effective decay control system to prolong fruit quality and shelf life.

\section{Literature Cited}

Aday, M. S., Buyukcan, M. B., and Caner, C. 2013. Maintaining the quality of strawberries by combined effect of aqueous chlorine dioxide with modified atmosphere packaging. J. Food Process. Preserv. 37:568-581.

Aday, M. S., and Caner, C. 2011. The applications of 'active packaging and chlorine dioxide' for extended shelf life of fresh strawberries. Packag. Technol. Sci. 24:123-136.

Allende, A., Tomás-Barberán, F. A., and Gil, M. I. 2006. Minimal processing for healthy traditional foods. Trends Food Sci. Technol. 17:513-519.

Arango, J., Rubino, M., Auras, R., Gillett, J., Schilder, A., and Grzesiak, A. L. 2016. Evaluation of chlorine dioxide as an antimicrobial against Botrytis cinerea in California strawberries. Food Packag. Shelf Life 9:45-54.

Arango, J., Rubino, M. I., Auras, R., Rachford, A. A., Bai, Z., Grzesiak, A. L., and Kijchavengkul, T. 2014. In situ quantification of chlorine dioxide gas consumption by fresh produce using UV-visible spectroscopy. J. Food Eng. 131:75-81.

Barmore, C., and Brown, G. 1985. Influence of ethylene on increased susceptibility of oranges to Diplodia natalensis. Plant Dis. 69:228-230.

Benarde, M. A., Israel, B. M., Olivieri, V. P., and Granstrom, M. L. 1965 Efficiency of chlorine dioxide as a bactericide. Appl. Environ. Microbiol. 13:776-780. 
Beuchat, L. R. 1996. Pathogenic microorganisms associated with fresh produce. J. Food Prot. 59:204-216.

Brown, G. E. 1975. Factors affecting postharvest development of Colletotrichum gloeosporioides in citrus fruits. Phytopathology 65:404-409.

Chen, H., McCollum, G., Baldwin, E., and Bai, J. 2016. Impacts of huanglongbing symptom severity on fruit detachment force and mechanical properties of sweet oranges (Citrus sinensis). HortScience 51:356-361.

Couri, D., Abdel-Rahman, M. S., and Bull, R. J. 1982. Toxicological effects of chlorine dioxide, chlorite and chlorate. Environ. Health Perspect. 46:13-17.

Du, J., Han, Y., and Linton, R. 2002. Inactivation by chlorine dioxide gas $\left(\mathrm{ClO}_{2}\right)$ of Listeria monocytogenes spotted onto different apple surfaces. Food Microbiol. 19:481-490.

Gómez-López, V. M., Ragaert, P., Jeyachchandran, V., Debevere, J., and Devlieghere, F. 2008. Shelf-life of minimally processed lettuce and cabbage treated with gaseous chlorine dioxide and cysteine. Int. J. Food Microbiol. 121:74-83.

Guo, Q., Wu, B., Peng, X., Wang, J., Li, Q., Jin, J., and Ha, Y. 2014. Effects of chlorine dioxide treatment on respiration rate and ethylene synthesis of postharvest tomato fruit. Postharvest Biol. Technol. 93:9-14.

Han, Y., Linton, R., Nielsen, S., and Nelson, P. 2001. Reduction of Listeria monocytogenes on green peppers (Capsicum annuum L.) by gaseous and aqueous chlorine dioxide and water washing and its growth at $7^{\circ} \mathrm{C}$. J. Food Prot. 64:1730-1738.

Ismail, M., and Zhang, J. 2004. Post-harvest citrus diseases and their control. Outlooks Pest Manag. 15:29-35.

James, J. 2006. Overview of microbial hazards in fresh fruit and vegetables operations. Pages 1-36 in: Microbial Hazard Identification in Fresh Fruit and Vegetables. J. James, ed. John Wiley And Sons Inc., Somerset, NJ.

Kader, A. A. 1991. Quality and its maintenance in relation to the postharvest physiology of strawberry. Pages 145-152 in: The Strawberry Into the 21st Century. A. Dale and J. Luby, eds. Timber Press, Portland, OR.

Keskinen, L. A., Burke, A., and Annous, B. A. 2009. Efficacy of chlorine, acidic electrolyzed water and aqueous chlorine dioxide solutions to decontaminate Escherichia coli O157: H7 from lettuce leaves. Int. J. Food Microbiol. 132:134-140.

Ladanyia, M. 2010. Citrus Fruit: Biology, Technology and Evaluation. Academic Press, San Diego, CA

Lee, Y., Burgess, G., Rubino, M., and Auras, R. 2015. Reaction and diffusion of chlorine dioxide gas under dark and light conditions at different temperatures. J. Food Eng. 144:20-28.

Lee, S.-Y., Costello, M., and Kang, D.-H. 2004. Efficacy of chlorine dioxide gas as a sanitizer of lettuce leaves. J. Food Prot. 7:1371-1376.

Mahovic, M. J., Tenney, J. D., and Bartz, J. A. 2007. Applications of chlorine dioxide gas for control of bacterial soft rot in tomatoes. Plant Dis. 91:1316-1320.

Montesinos-Herrero, C., Smilanick, J. L., Tebbets, J. S., Walse, S., and Palou, L. 2011. Control of citrus postharvest decay by ammonia gas fumigation and its influence on the efficacy of the fungicide imazalil. Postharvest Biol. Technol. 59:85-93.

Paniagua, A., East, A., Hindmarsh, J., and Heyes, J. 2013. Moisture loss is the major cause of firmness change during postharvest storage of blueberry. Postharvest Biol. Technol. 79:13-19.

Park, S.-H., and Kang, D.-H. 2015. Antimicrobial effect of chlorine dioxide gas against foodborne pathogens under differing conditions of relative humidity. LWT Food Sci. Technol. 60:186-191.

Plaza, P., Sanbruno, A., Usall, J., Lamarca, N., Torres, R., Pons, J., and Viñas, I. 2004. Integration of curing treatments with degreening to control the main postharvest diseases of clementine mandarins. Postharvest Biol. Technol. 34: 29-37.

Ritenour, M. A., Zhang, J., and Dewdney, M. M. 2016. Control of stem-end rot of fresh citrus. Citrus Industry October 2016:12-15. https://crec.ifas.ufl. edu/media/crecifasufledu/extension/extension-publications/2016/2016_October_ stem.pdf

Saunt, J. 1990. Citrus Varieties of the World. An Illustrated Guide. Sinclair International Ltd., Norfolk, United Kingdom.

Smilanick, J., Brown, G., and Eckert, J. 2006. The biology and control of postharvest diseases. Pages 339-396 in: Fresh Citrus Fruits, 2nd Ed. W. F. Wardowski, W. M. Miller, D. J. Hall, and W. Grierson, eds. Florida Science Source, Inc., Longboat Key, FL.

Smith, D., Ernst, W., and Herges, G. 2015. Chloroxyanion residues in cantaloupe and tomatoes after chlorine dioxide gas sanitation. J. Agric. Food Chem. 63:9640-9649.

Sun, X., Bai, J., Ference, C., Wang, Z., Zhang, Y., Narciso, J., and Zhou, K. 2014. Antimicrobial activity of controlled-release chlorine dioxide gas on fresh blueberries. J. Food Prot. 77:1127-1132.

Sun, X., Baldwin, E., and Bai, J. 2019. Applications of gaseous chlorine dioxide on postharvest handling and storage of fruits and vegetables - a review. Food Control 95:18-26.

Sun, X., Baldwin, E., Ference, C., Narciso, J., Plotto, A., Ritenour, M. Harrison, K., Gangemi, D., and Bai, J. 2017a. The effect of controlledrelease chlorine dioxide on the preservation of grapefruit. HortScience 52: 122-126.

Sun, X., Zhou, B., Luo, Y., Ference, C., Baldwin, E., Harrison, K., and Bai, J. 2017b. Effect of controlled-release chlorine dioxide on the quality and safety of cherry/grape tomatoes. Food Control 82:26-30.

Sy, K. V., Murray, M. B., Harrison, M. D., and Beuchat, L. R. 2005. Evaluation of gaseous chlorine dioxide as a sanitizer for killing Salmonella, Escherichia coli O157: H7, Listeria monocytogenes, and yeasts and molds on fresh and fresh-cut produce. J. Food Prot. 68:1176-1187.

Trinetta, V., Vaidya, N., Linton, R., and Morgan, M. 2011. Evaluation of chlorine dioxide gas residues on selected food produce. J. Food Sci. 76:T11 T15.

Wang, L., Sokorai, K., Wu, V. C. H., and Fan, X. 2019. Gaseous chlorine dioxide maintained the sensory and nutritional quality of grape tomatoes and reduced populations of Salmonella enterica serovar Typhimurium. Food Control 96:299-309.

Wang, Y., Wu, J., Ma, D., and Ding, J. 2011. Preparation of a cross-linked gelatin/bacteriorhodopsin film and its photochromic properties. Sci. China Chem. 54:405-409.

WHO. 2002. Chlorine dioxide (Gas). Concise International Chemical Assessment Document 37. World Health Organization, Geneva, Switzerland.

Zhang, J. 2007. The potential of a new fungicide fludioxonil for stem-end rot and green mold control on Florida citrus fruit. Postharvest Biol. Technol. 46:262-270.

Zhang, J. 2014. Lasiodiplodia theobromae in citrus fruit (diplodia stem-end rot). Pages 309-335 in: Postharvest Decay. S. Bautista-Baños, ed. Academic Press, San Diego, CA.

Zhao, W., Bai, J., McCollum, G., and Baldwin, E. 2015. High incidence of preharvest colonization of huanglongbing-symptomatic Citrus sinensis fruit by Lasiodiplodia theobromae (Diplodia natalensis) and exacerbation of postharvest fruit decay by that fungus. Appl. Environ. Microbiol. 81: 364-372. 